\title{
Maria Edgeworth for Italian Readers: An Analysis of Bianca Milesi's Benedetto (1839)
}

\author{
Carmen María Fernández Rodríguez \\ EOI Santiago de Compostela/Universidade da Coruña \\ c28fernandez@gmail.com
}

\begin{abstract}
Maria Edgeworth (1768-1849) was one of the most prominent British writers at the turn of the nineteenth century. In addition to pedagogical essays and feminocentric fiction, this Anglo-Irish authoress produced some tales for children which were quickly translated into a number of European languages. This paper is part of a larger project which considers the reception of Edgeworth's oeuvre on the Continent, and analyzes the Italian version of one of her last fictions for children, Frank (1822). Bianca Milesi's rendering of the text into Italian will be studied within the framework of translemic studies. For this purpose, we will contextualize Edgeworth's educational work and make reference to the impact of Milesi's books in literary magazines and her relationship with Edgeworth. Though the readers of the source and target texts remain the same, Benedetto is conditioned by Milesi's personality and historical circumstances. As a result, there is a balance between fidelity to Edgeworth's Frank regarding the main plot and characterization, and the will to adapt the story to a new context through a number of suppressions which affect the macro and microstructure of the text. There are also some additions, these intended to bring Frank closer to young Italian readers. This article suggests that, rather than a translation, the changes in the target text point to an adaptation of Edgeworth's narrative.
\end{abstract}

Keywords: Maria Edgeworth, translation studies, Italian, gender studies, nineteenth-century literature 


\section{Introduction}

The translation of Maria Edgeworth's works in Italy during the nineteenth century has thus far received little attention. ${ }^{2}$ The aim here is to study the Italian version of Frank, A Sequel to Frank in Early Lessons (1822) (hereafter Frank, which was translated into Italian as Benedetto) by means of a translemic analysis within the framework of gender studies and following the lines of previous research on Edgeworth's reception on the Continent (Fernández, 2008; 2010; 2012; 2013a). We will, then, examine the work of a well-known Italian thinker who was deeply involved in Italian politics at the turn of the nineteenth century.

After a contextualization of the translator and her age, the target text will be analyzed in light of the source text, drawing on Even-Zohar's theory of the literary system understood as a network of relations between elements (producer, consumer, market, product, institution and repertoire) which are integrated and mutually dependent (Even-Zohar, 1990: 34). Even-Zohar's theory is useful for our purpose since it considers literature within a dynamic relationship with the social context. On the one hand, and as Gideon Toury has noted, translations fill the gaps in the target culture (1995: 27), and become part of a new literary polysystem with the help of the educational system and literary critics (comments, introductions, summaries). On the other hand, to claim that translated literature maintains a central position in the literary polysystem implies that it participates actively in shaping the centre of the polysystem. In such a situation, translation constitutes an integral part of innovatory forces, and it is likely to become one of the means of elaborating a new repertoire (Even-Zohar, 1990: 46-47), which is especially interesting when we deal with a specific section of the polysystem, such as children's literature, and its specific constraints. The descriptive translemic analysis to be performed here cannot neglect cultural factors. It considers macrotextual aspects, such as, the narrative point of view, prologues, footnotes, etc, and microtextual ones, including the study of units of analysis and the segments established between texts, as well as the deviations or modifications that operate within them (Snell-Hornby, 1995).

\section{The English text}

Maria Edgeworth (1768-1849) was one of the most popular and prolific women writers in nineteenth-century Great Britain. She can be credited with having introduced both the regionalist novel and the Big House novel with Castle Rackrent (1800), a text which inspired her great friend Sir Walter Scott, and later, Ivan Turgenev. The former referred to Edgeworth in the General Preface to his Waverley Novels as follows: "she may be truly said to have done more towards completing the Union than perhaps all the legislative enactment by which it has been followed up" (1877: 420). Current Edgeworth studies tend to focus on Ireland, Edgeworth's position towards the Union, 
the Empire or Edgeworth's enlightened views on education and woman. The AngloIrish authoress's corpus is quite complex and comprises Irish tales (Ennui [1809], The Absentee [1812]), pedagogical essays (Practical Education [1801]), and novels of manners (Belinda [1801], Helen [1834]). In fact, Edgeworth was of primary importance in terms of the novel of manners before the success of Jane Austen in the twentieth century, and soon became popular in the French-speaking world where she was highly praised, to the point that the rationalist philosopher André Morellet explained: "À Paris on lit votre livre sur l'éducation -à Genève on l'avale- à Paris on admire vos principles - à Geneve on les suit [in Paris, they read your book on education -in Genoa they devoured it - in Paris they admire your principles - in Genoa they follow them]" (Butler, 1972: 190). Thanks to the translations of her Swiss friends Charles and Marc-Auguste Pictet in Bibliothèque Britannique, versions of Edgeworth's works circulated all throughout the Continent.

Frank is part of Early Lessons, a series of stories which also includes Harry and Lucy, Frank and Rosamond (1801), Continuation of Early Lessons (1814), Rosamond: A Sequel (1821) and Harry and Lucy Concluded (1825). It developed from Harry and Lucy's stories and was intended as an introduction to science for Maria's half-brother William. After Richard Lovell's death, Maria used the notes her father had left to compose the stories, but she had to consult friends and confessed her doubts in a letter to Walter Scott, dated the 8th of April 1825: "The toil, difficulty, mortification I have gone through in finishing these last volumes without him is not to be described ... I have no science; and, as to accuracy, can compare myself only to the sailor who 'would never quarrel for a handful of degrees'. I trust my friends have saved me from public shame" (qtd. in Butler, 1972: 167). Over the years, characters evolve: in Frank, the heroes grow from seven to eleven, in Rosamond the heroine is between ten and thirteen, and in Harry and Lucy the main characters reach fourteen (Butler, 1972: 168). Elizabeth McWhorten is very critical in her assessment of Early Lessons. For her, Frank's father is a caricature and is not genuinely concerned with his children's best interests. Children are also forced to learn through encounters which are not only painful and dangerous but also improbable. Furthermore, Frank is a tiresome prig, a miniature Sir Charles Grandison and his experiences are nothing more than a variation on the theme of goodness. According to McWhorten, when a child possesses the virtues that Edgeworth wants to inculcate, he is no longer a child (1971: 37-39).

The idea behind Early Lessons is the same as in Practical Education: to plant the seeds of science, morality and other areas of thought in the small child's conscious or partly conscious mind (Butler, 1972: 64). In the "Preface to Parents", it is stressed that going to a public school does not necessarily mean becoming a great man. Home education is very important since a parent teaches principles and can control children in a way a schoolmaster cannot. At school, it shows if home education has been appropriate (Edgeworth, 1822: 6). The following volumes are about Frank, a sevenyear-old boy whose goal is to become self-controlled and manly. The latter does not mean unruly, but rather "abiding by his conviction, and his resolution; in defying ridicule, and in resisting all that is wrong in every shape" (Edgeworth, 1822: 10). The 
mistakes of parents are also dealt with, such as being too anxious and being willing to offer children an unpractical education.

The plot is similar to those of Edgeworth's other fictional works for children. When the story begins, Frank and Mary meet a spoilt schoolboy, Tom, who comes to visit the family with his mother, Mrs. J. The children do not understand his speech and Tom warns Frank that he should learn Latin before going to school or he will be flogged. Frank is terrified at the idea, while also observing Tom's apathy. Frank begins to learn Latin on his own, but, instead of being motivated, he feels bored and is easily distracted. His father brings home a beautiful horse, Felix, which engages Frank's attentions. Gradually, Frank shows more courage. He meets a gardener and his son, a very intelligent boy who is teaching himself mathematics with the aim of being able to earn a living as a teacher when he is older. Frank realizes that even a manual worker needs to know the classics, and indeed he sees that the gardener reads Virgil.

During the autumn, Frank meets an engineer and also a prejudiced country Squire, Rugers. The former shows Frank a telescope and other instruments and the hero begins to use these. The boy's mother tries to make him learn ancient history and the history of England, and also gives him a task to do with Mary: they are to produce a chart representing the historical periods. However, rather than work towards finishing the chart, they continually put it off, and the task is never completed. The engineer gives Frank a month to learn the change of seasons, which he finally manages to do, and hence he is given more material to study. He builds an orrey which he later shows the engineer's son, Lewis, who is Tom's opposite and becomes a good friend. Unfortunately, Frank's desire to attend Lewis's school is frustrated because there is no vacant place for him.

The family pays a visit to the Crepstows and Frank meets Horace Granville, who is being educated at one of the best schools in England. During this part of the story, Frank has contact with several young people who are equally ill-tempered and malignant, and he comes to realize that he will have to decide if he wants to be a fag or a flatterer. After being constantly teased and quizzed (Edgeworth, 1822: 198-200), Frank is persuaded that he would not be happy if he were educated like them. Finally, the family leaves Bellombre and some good news arrives: a position has become vacant for Frank at Lewis's school.

\section{Milesi and the reception of her translations in the Italian press}

Bianca Milesi Mojon (1790-1849) was an Italian patriot and writer who admired Edgeworth and popularized her ideas in Italy. She belonged to an aristocratic family, the Viscotinis, on her mother's side and was brought up in Milan. Having studied at a convent in Florence, Bianca showed great intellectual curiosity and dreamed of becoming a painter, so she headed for Rome, where she was acquainted with the sculptor Antonio Canova and the feminist Sophia Reinhard (1775-1843), a German artist and follower of Saint Simon. Back in Milan, Milesi was deeply involved in politics and joined the feminist movement "Le giardiniere" and the secret society "I 
federati". She was acquainted with Carlo Cattaneo, Alessandro Manzoni and Carlo Porta, and it seems that the political economist Melchiore Gioja dedicated to her Delle Ingiurie dei danni, del soddisfacimento e relative basi di stima davanti ai tribunali civili (1821) after his release from prison, as a mark of gratitude in that Milesi had contributed to his liberation (Maroncelli of Forli, 1836: 57). Not only did she invent the "carta frastagliata [indented paper]", a method to read coded messages, but together with Count Federico Confalonieri and Count Giuseppe Pecchio she founded the Scuole di Mutuo Insegnamento, to promote common national and cultural awareness. The schools were closed down by the Church, who had the monopoly on education at the time. In 1822, Milesi left for Geneva, where she had contact with the economist Jean Charles Leonard Simonde de Sismondi and also came to know Edgeworth's works, probably through Étienne Dumont. Following her marriage to Dr. Benedetto Mojon in 1825, her household became a meeting point for Romantic intellectuals, aristocrats and members of the bourgeoisie. Milesi was a feminist ad litteram and was kept under police surveillance due to her independent and extravagant character. They called her "La giovane energumena" and even interrogated her.

During her lifetime, Milesi wrote letters to Lady Byron and also corresponded with Louise-Swanton Belloc, the daughter of an Irishman and Edgeworth's translator in France (Colvin, 1979: 289-290). Admired by Manzoni and a philanthropist deeply committed to the education of children, the Italian writer appreciated Edgeworth so greatly that the last letter Milesi wrote was to Signora Fulvie communicating Edgeworth's death (Souvestre, 1854: 122). Milesi received one letter from Edgeworth in 1830 after the publication of Prime lezioni. The Anglo-Irish writer was thankful to her because Benedetto - was more agreeable than Frank and the book was beautifully written: "il parle votre langue avec tant de grâce et de poésie, que je ne puis m'empêcher de croire qu'elle est sa langue maternelle. J'ajouterai que son nom italien Benedetto promet davantage, est plus conciliant, plus béni (pardonnez ce mauvais jeu de mot) que celui de Franck, qu'il portait en Angleterre [he speaks your language so gracefully that I believed it was his first language. I would like to add that his Italian name, Benedetto, is more promising, more conciliatory, more accurate (excuse me for this awful wordplay) than Frank, which he had in England]" (Souvestre, 1854: 66-67). On that occasion, Edgeworth congratulated Milesi and invited her to Ireland, which she described in positive terms:

Les libertés civiles et religieuses se joignent aux bienfaits d'un pays fertile en coeurs chalereux, en esprits actifs, en mains laborieuses (je parle sans exaggeration), nous pouvons espérer que les Irlandais s'élèveront sur l'échelle des peuples. Ils montréront qu'ils peuvent supporter la prospérité aussi bien, bien meme qu'ils n'ont supporté l'adversité. Je suis sans inquiétude maintenant pour l'Irlande [Civil and religious liberties gather together in a fertile country of passionate hearts, of enterprising spirits, of labouring hands (I do not exaggerate). We hope the Irish will stand out among people. They will show they can stand prosperity as well as they endured adversity. Now I am not worried about Ireland] (Souvestre, 1854: 6667). 
The close relationship between Edgeworth and Milesi is understandable if we turn to Italian history and the politics of the period. The nineteenth-century Risorgimento led in 1861 to national unification and established the cultural foundations for the Italian state: national conscience had been aroused and a series of political events freed the Italian states from foreign domination, in that the desire for freedom was accompanied by a yearning for liberalism and constitutionalism. The opposition to the Austrian Empire coloured all literary writings in one way or another. Along with the education of the citizens of the new Italy and the italianità, the idea of the motherland became the main literary topic, and would continue thus even into the twentieth century (Bravo, 1989: 28; Peña, 1994: 115-116). Both Edgeworth and Milesi were deeply attached to their countries. The former had written extensively on the Union of Ireland and Great Britain and its consequences. For Milesi, Ireland was a country to emulate and Edgeworth a writer to sympathize with.

Italian periodicals soon saw the achievement of Milesi, who was behind the translation of other authoresses, including Anna Letitia Barbauld's children's book Inni sacri in prosa per fanciuli (Napoli: G. Nobile, 1835). Curiously, when commenting on Milesi's achievement, Edgeworth was always in the spotlight and reviewers attacked Milesi on the same grounds as Edgeworth (Author, 2013b). Prime lezioni was reviewed in Antologia: giornale di scienze, lettere e arti, where it was said to be "trasunto del sistema della sig. Edgeworth [an image of Miss Edgeworth's system] and a complement of it" (1831: 134). In the review of Prime lezioni in Indicatore, the reviewer amply reflects on education and stresses that God is never mentioned in the book (1835: 444). Later, in Guida dell'educatore, there is a review in the form of a correspondence between two readers about Edgeworth's tales. The first reader expected that Colazioni della nonna was an imitation of Edgeworth and feels disappointed: this reader thinks that the story of the cracked eggs in Prime lezioni is "un semplice vero insegnamento imitabilissimo da ogni madre assennata, ed è lettura grata ed edificante per bambini [true lessons to be imitated by every sensible mother and a pleasing edifying reading for children]" (1836: 102). The other correspondent sees a problem in Edgeworth's production: "se i libri della Edgeworth fossero un pochino più caldi di sentimento, e pochino più animate dall'immaginazione, non vi sarebbe poi nessun male [if Edgeworth's books were a little warmer and more imaginative, they would be better]" (1836: 104). The second correspondent goes on to defend some German books about the love for nature and pure feelings. If they were combined with Edgeworth's works, as it is argued, children might be able to cultivate themselves; otherwise, they will become sensible, but not natural children (1836: 105). As for Italian children, they love romances and comedies, which should be harnessed by such works to make them more reflexive. The second correspondent thinks that Milesi will be appreciated in the future, not now (1836: 106). Guida dell'educatore advertises some translations by Milesi: Storiette per lettura dei bambini (second edition 1833) and Prime lezioni; the guide highlights Edgeworth's love for truth and candour while some people are "avveze a divertirsi con avventure commoventi [avid to enjoy exciting adventures]" (1836: 39). 
Rivista Europea: giornale di scienze morali, letteratura ed arti listed two of Milesi's productions: Educazione famigliare o serie di letture per fanciulli della prima età sino all'adolescenzia (Bologna 1833, due volume) and Benedetto. They considered the former the best volume for children, together with Marenesi's Novelliere per giovanetti. After pointing out the differences between the French and Anglo-Irish authors - mainly that the former focuses on fantasy and feeling-, they regard Edgeworth's tales as "una miniera preziosa di osservazioni morali ma si rivolgono più all'intelletto che all'animo [a treasure trove of moral observations but they address the intellect rather than the heart]" (1846: 240). Italian reviewers could not overcome the traditional image of English people as introvert and melancholic, and admitted that for Italian readers it was difficult to identify themselves with Edgeworth. On the one hand, "I fanciulli da lei prediletti sono piuttosto parvoli rimbambiti, che non piccholi uomini [the children she loves are stupid children rather than little men]" (1846: 241). On the other hand, Edgeworth dialogues were too long and difficult to follow, and she did not believe in children's instinctive mental activity, envisioning children in simple terms.

\section{The Italian version}

Applying Even-Zohar's model, in the source text, Edgeworth is the producer responsible for a product (Frank) addressed to British readers. She has in mind a market composed by a young audience who appreciated didactic fiction. The critics, publishing houses and universities, are part of the institution, which generally supported Edgeworth. Finally the repertoire establishes the rules and materials governing both the production and use of that product. In Edgeworth's case, this refers to the educative tale represented by Anna L. Barbauld (Evenings at Home [1796]).

The producer of the target text, Milesi, does not specify the source she is using for her product (Benedetto). Her readers are clearly defined in the paratext (Genette, 1987: 7) preceding the main text, although she obviously has in mind a broader audience, one composed of the Italian higher and middle-classes as her market. For Genette, dedicating a work comprises some ostentation or exhibition: "[la dédicace] affiche une rélation, intellectuelle ou privée, réelle ou symbolique, et cette affiche est toujours au service de l'oeuvre, comme argument de valorisation ou thème de commentaire [the dedication makes public a relationship, intellectual or private, real or symbolic, and that notice is always at the service of the work as an argument of valorization or topic of comment]" (1987: 126). As a matter of fact, Benedetto is dedicated to a woman, precisely to one of Honore de Balzac's friends, the noblewoman Countess Sanseverino Porcìa, and Milesi explains that she aims to offer the Countess "preziose norme per l'educazione de' cari vostri figlioletti [valuable advice for the education of your dear little children]" (Edgeworth, 1839: V). The translator also states that she does not depart much from the original, as it was already indicated in the preface to Prime lezioni.

Regarding the institution and the repertoire, we might consider reviewers' positive response to Milesi's work and her choice of the Tuscan dialect and simple vocabulary, as is common in texts for young readers: "The reason for the high style in children's 
literature is connected with the didactic concept of literature and the attempt to enrich the children's vocabulary" (Shavit, 1981: 177). The Tuscan dialect had been the standard for Italian literature since the Renaissance. Manzoni had revised I promessi sposi recasting it into the Tuscan dialect, and in this way reflecting the nationalistic project of unifying Italy through its language and literature, and establishing a linguistic model which could be understood by most Italian readers. Nevertheless, Milesi's choice had been previously criticized. When Biblioteca italiana reviewed the first edition of Prime lezioni, they did so with a philological approach and it was pointed out that translating familiar and specialized language like that which Edgeworth introduces in her works is not easy, and that Milesi had made several mistakes (1829: 278); the result, it is argued, is an opaque text for young readers. There are, for example, orthographic mistakes and a glossary appended by Milesi with comments about archaic language. ${ }^{3}$ For the reviewer of Prime lezioni in Indicatore, it seems that Milesi does not present a literal translation since she substituted some terms for non equivalent ones in an attempt to achieve "propietà di parole [propriety of language]" (1835: 445), which is linked to the attempt to provide children with the best linguistic models. The reviewer states that Milesi is engaged in the attempt to unify Italian, and quotes Milesi explaining that she chose the dialect from Tuscany to "agevolare la cognizione del vocabolario domestico, ed a fortificare così sempre più quei vincoli che legano ogni provincia d'Italia ad una patria comune [facilitate the knowledge of domestic vocabulary and fortify forever those ties which bind every province in Italy to a common motherland]" (1835: 446). Milesi was an innovator in that she translated literature for children in Italy before Carlo Lorenzini, Collodi, Edmundo D'Amici or Pietro Paravicini, and the Italian polysystem did not have a native literature similar to Edgeworth's work.

As a whole, the target text complies with the principles of acceptability and adequacy in that it adheres to the norms of the target and source cultures respectively (Toury, 1995: 56-57). Nonetheless, the target text reveals some carelessness, with omissions and obvious mistakes. Some parts of the preface do not appear in the translation, especially those dealing with "public education": "it would be a sufficient consolation, or quieting to their conscience, to throw the blame upon the negligence of the schoolmaster, and the vices of our public institutions" (Edgeworth, 1822, I: 7) or "and by what means they may give to their boys the greatest school chance of securing every advantage to be hoped from public education" (Edgeworth, 1822, I: 7-8). There are also typographical errors or slips which are perhaps the consequence of translating too quickly: Sandford and Merton (Edgeworth, 1822, I: 112) becomes "Sandford and Berton" (Edgeworth, 1839: 99) and "Phileros" (Edgeworth, 1822, II: 76) turns into "Fileno" (Edgeworth, 1839: 328).

One of the strong points in Edgeworth's stories is the literary representation of speech. She repeatedly showed her ability to brilliantly reproduce Anglo-Irish speech and children's discourse. Milesi makes an effort to render Frank's ideolect into Italian when he reasons with the horse:

"My dear Felix, don't be foolish — it's only the turkey-cock. Stand still, Felix — stand still. Oh, Felix! Felix! for shame, Felix : you are a greater coward than I was, when I was - Oh, 
Felix, fie ! you'll throw me on the dunghill, if you don't take care - do stand still. Do hush! turkey-cock! What a horrible hobble-gobbling you are making — stand still, I say, sir! stand still!" (Edgeworth, 1822, I: 91).

"Via, caro Felice, non fare il matto, non temere: non è altro che un tacchino. Sta fermo, Felice, sta fermo. Oh, Felice! Felice! Oibò! Sei ancor più codardo che non ero io, quando fui qui tempo fa. Oh Felice! Oibò! .... Tu mi butterai sul letamaoi se hon hai guidizio: sta fermo. - Zitto, brutto tacchino, col tu glu glu! - Fermo, Felice! Via, signor Felice, vi dico di star quieto [Come on, dear Felix, don't be foolish, don't be afraid: it's only a turkey. Be quiet, Felix, be quiet. Oh, Felix! Felix! for shame, Felix: you are a greater coward than I was long time ago. Oh Felix! Stop!... you'll throw me on the pigpen if you don't use your judgment: be quiet. Hush! ugly turkey, with your gobbling! - Be quiet, Felix! Come on, Mr. Felix, I tell you to be quiet]" (Edgeworth, 1839: 78).

Prior to Even-Zohar, another scholar had focused on the translation of children's literature. Zohar Shavit maintained that the systemic affiliation of a text which enters the children's system is not very different from a text which enters the non-canonized system of adults (1981: 172-173). However, in order to affiliate the original text to existing models, a simplification may be in operation, either changing the function of some elements, the reduction of other functions, or even the suppression of the function of some features (Shavit, 1981: 176). These features are traceable in transition from English to Italian, plus in another sense: first, there are some suppressions and reductions from the source text; second, a good deal of references, as well as the setting and certain linguistic expressions, are adapted to Italian and to the new audience; third, some information is added to facilitate comprehension for the target readers.

\subsection{Suppressions and reductions}

Shavit states that the target text can be changed by deleting elements in order to adjust it to the model which absorbs it in the target literature (1981: 172-173). Naturalizing the translation implies leaving out unnecessary information from the original. For instance, an explanation about English grammar is logically erased in Italian: "The subjunctive mood differs not in form from the potential, but is always rendered into English as if it were the indicative" (Edgeworth, 1822, I: 38). Edgeworth's story relies heavily on references to British culture, which are lost in Milesi's version: a garret at Lichfield (Edgeworth, 1822, I: 113), The Gentleman's Magazine (Edgeworth, 1822, I: 142), Lieutenant George Spearing (Edgeworth, 1822, I: 142), Joyce's Scientific Dialogues (Edgeworth, 1822, I: 231), Dr. Priestley (Edgeworth, 1822, II: 64), Bingley (Edgeworth, 1822, II: 69) or the reference to Henry VIII in the squire's speech:

"Have a care, or the horse will kill you," cried the squire, drawing his horse back, with a look of terror; "Stamper will have his fore paw in your stomach, and knock you down, dead as king Harry the Eighth. Ods my life! you frightened me, man, and I'm not easily 
frightened a-horse back ; but, Frank, you're like a boy I lost, that was worth his weight in gold," said the squire, taking off his hat, and wiping his forehead (Edgeworth, 1822, I: 203, my italics).

"Badate, vi farete ammazzare (gridò il cavaliere, ritenendo il suo cavallo, con un'aria di terrore)". "Stampo farebbe più presto a cacciarvi le quatro zampe sul petto, che non io a dir badate. Cospetto di Bacco! che paura mi avete fatto, ragazzo mio; e si che non son facile a impaurire quando sono a cavallo; ma voi, Benedetto, somigliate a un figliuolo che mi è morto, e che valeva tant'oro quanto pesava" ["Be careful, or you will be killed (the gentleman cried as he drew his horse back with a look of terror)". "Stamper would more quickly throw his paws on your chest than I would look after you. For Baccus' sake! you frightened me, my boy: and I am not easily frightened when I am riding; but you, Benedetto, you look like my son who passed away and was worth his weight in gold]" (Edgeworth, 1839: 192-193).

Paratextual elements are related to adequacy. They emphasize the didactic aspect of the work, highlight moral actions or explain difficult terms for the target reader. Thus, neither the footnote about key-stones (Edgeworth, 1822, I: 18) nor the note about the Edinburgh Review (Edgeworth, 1822, II: 251) are in Italian. As a result of infratranslation (Newmark, 1995: 285), the target reader is deprived of cultural information and ambiguous passages deserving attention, which is especially important when dealing with children's literature and with an enlightened writer like Edgeworth. The same happens with the disappearance of culture-specific elements and literary allusions, so the lines Frank remembers from "The Peacock at Home" are erased from the Italian version:

They censured the bantam for strutting and crowing.

In those vile pantaloons, which he fancied look'd knowing:

And a want of decorum caused many demurs,

Against the game chicken, for coming in spurs (Edgeworth, 1822, I: 93).

There are also important reductions regarding cultural references, and intertextuality is not respected: "The officers then began to talk to one another of the different battles in which they had been, in Spain, France, and Flanders. First they spoke with triumph of the battle of Waterloo" (Edgeworth, 1822, I: 214) becomes "Gli ufficiali incominciarono a parlare di varie battaglie con un'aria di trionfo [the officers began to talk of various battles with a triumphant air]" (Edgeworth, 1839: 204). The reference to Milton's Samson Agonistes into Latin, and of Herodotus and Sophocles' Oeddipus Tvrannus in Greek (Edgeworth, 1822, II: 65) is reduced to "Virgilio, Erodoto and Sofocle" (Edgeworth, 1839: 316). Some lines that Frank repeats from the Iliad (Edgeworth, 1822, I: 225, 227) are considerably reduced (Edgeworth, 1839: 216, 218), two unidentified lines in the original disappear (Edgeworth, 1822, I: 240) while others are preserved in English:

[...] to come in spite of sorrow, 
And at my window bid good morrow,

Tbrough the sweetbriar, or the vine,

Or the twisted eglantine (Edgeworth, 1822, II: 42).

\subsection{Adaptation to Italian culture}

This is one of the most important features of this translation. According to Göte Klinberg, the adaptation of cultural context involves explaining certain information to the child and assuming his/her lack of knowledge (1986: 65). For Klinberg, "children's literature is produced with a special regard to the (supposed) interests, needs, reactions, knowledge, reading ability and so on of the intended readers" (1986: 7). Shavit points out that the translator of children's literature can permit himself great liberties regarding the text due to the peripheral position children's literature occupies in the polysystem: he is allowed to manipulate the text as long as his adjustments make the text appropriate and useful to the child, in accordance with what society thinks is "good for the child", and that he adjusts plot, characterization and language to the child's level of comprehension and reading ability (1981: 171-172).

In Milesi's version, adapting the text implies changing proper names and measurements, which was paramount in children's literature at that time. Names are translated when there is an equivalent in Italian: "Thom" becomes "Tomasso", "Felix" is rendered as "Felice", "Billy/Willy" shifts to "Guglielmo", "Andrew" is transformed into "Andrea", "George" turns into "Giorgio", "Pompey" is translated as "Pompeo", "Catherine" changes into "Caterina" and "Lewis" into "Luigi". Hypocorisms are retained: "Birch" is translated as "Nerbo [Scourge]", "Blacky" becomes "Moretto" and "Stamper" becomes "Stampo". There is a mistake in the translation of "Mrs. J" as "La signora I". More problems are found when the translator renders other names into Italian: "Headlong" (Edgeworth, 1822, I: 159) becomes "scappato [run away]" (1839: 146), "Mr. Cockahoop" (Edgeworth, 1822, I: 207) becomes "signor saccentello [Mr. Know-it-all]" (1839: 197) and Mr. Bright appears as "Il signor Britti". On the contrary, Poll is not altered.

In the chapter on animals, children have to choose their favourite ones. Milesi substitutes the English names for familiar ones: "young Little" (Edgeworth, 1822, II: 72) becomes "Enrico Milesi"4 (Edgeworth, 1839: 324), "Miliken" (Edgeworth, 1822, II: 72 ) is changed to "Emilio Rossi" (Edgeworth, 1839: 324), "Edgeware" (Edgeworth, 1822, II: 72) to "Cesare Luca" (Edgeworth, 1839: 324), "Joe Thompson" (Edgeworth, 1822, II: 72) to "Genaro Viscotini" (1839: 325) and "young Flaxman" (Edgeworth, 1822, II: 73) becomes "giovane Belloti” (Edgeworth, 1839: 325).

Measurements are also adapted: "a scale of one twentieth of an inch to afoot" (Edgeworth, 1822, I: 177) is translated as "Scala d'un ventesimo di decimetro per metro [a scale of one twentieth of a decimetre per metre]" (Edgeworth, 1839: 162) and "foot rule" (Edgeworth, 1822, I: 176) is rendered as "il braccio di Milano [Milan's fathom] (Edgeworth, 1839: 164). The conversation "We will draw it by a scale of a tenth of an inch to a font. Eighty tenths of an inch, how many whole inches is that?' Frank instantly answered, 'Eight"” (Edgeworth, 1822, I: 177) is rendered as "'Disegneremo in una scala 
di un centimetro per metro. Trenta centimetri quanti decimetro fanno?' Benedetto rispose subito: 'Tre decimetri ['We will draw in a scale of a centimetre per metre. Thirty centimetres, how many decimetres is that?' Benedetto quickly answered: 'Three decimetres']" (Edgeworth, 1839: 164). "Miles" (Edgeworth, 1822, II: 33) becomes "miglia" (Edgeworth, 1839: 281). "Guineas" (Edgeworth, 1822, I: 85) turns into "luigi [guinea]" (Edgeworth, 1839: 72). "Pounds, shillings, and pence" (Edgeworth, 1822, II: 12 ) is rendered as "soldi e in denari, poi ridurla in fanchi e in centesimi [money and deniers, then decreased into francs and cents]" (Edgeworth, 1839: 258).

Madera's story (Edgeworth, 1822, I: 173) preserves the English setting, but cultural references are generally adapted to the context and to Italian readers: "I should like to build one of the London bridges, of which we have a print or Westminster Abbey, or York or Litchfield Cathedral or a Roman triumphal arch" (Edgeworth, 1822, I: 16) is rendered with references to Firenze and San Pietro (Edgeworth, 1839: 2), and "what English book do you read?" (Edgeworth, 1822, I: 25) becomes "che libro italiano leggete? [what Italian books do you read?]" (Edgeworth, 1839: 11) With the phrase "and fitting for Westminster or Eton, and then we must get on to Oxford or Cambridge" (Edgeworth, 1822, I: 28), the translation suppresses cultural words, such as Westminster and Eton: "bisogna entrare in filosofia, per poi andare all'università [it is necessary to enter into philosophy to go to university later]" (Edgeworth, 1839: 15). The English civil wars and Cromwell (Edgeworth, 1822, I: 129) become the Italian civil wars (Edgeworth, 1839: 117). In this regard, a very interesting feature is the transformation of England into Lombardia, a prosperous Italian region:

[...] that he deserved, indeed, to have a spirited horse; and that he would not, for a guinea, that any young gentleman, but himself, should have had Blacky, he looked so well on him; that a fine young gentleman should always have a fine young horse; that he was certain master Frank would, in time, make the finest young gentleman rider in the whole country, or the nest, or in the three ridings of Yorkshire (Edgeworth, 1822, I: 89).

che egli meritava davvero aver un cavallo vivace, e che en quanto a lui e'non vorrebbe per un luigi che Moretto fosse tocato ad altri che a lui, chi ci faceva una così bella comparsa, e che un gentile signorino come lui doveva anche avere un cavalo gentile. Lo assicurava che col tempo e'sarebbe il più bel giovane cavaliere di tutta Lombardia [that he really deserved to have a spirited horse and that he would not, for a guinea, allow any gentleman, but him, to touch Moretto, which always made him look fine, and that a gentlemen like him should always have a good horse. He was certain that in the future he will turn into the most handsome gentleman rider in Lombardia] (Edgeworth, 1839: 79).

Again, when children go to a farm "trotting through pretty lanes, and cantering across a common, they came to Copsley Farm; a farm which had been lately purchased by farmer Lee" (Edgeworth, 1822, I: 90), the scene is rendered as "attraversarono un villaggio, poi giunsero alla cascina del Pero che era stata ultimamente comperata dal fittaiuolo Leone [they went through a village, then arrived to the hampstead of Pero which had been lately bought by Farmer Lee]" (Edgeworth, 1839: 77). "A trigonometrical survey of England" (Edgeworth, 1822, I: 126) appears as "catasto della 
Lombardia [land register of Lombardy]" (Edgeworth, 1839: 113). England then changes to Lombardy once again: "He was surprised to learn, that an arch and a road, which he now saw, had been made when the Romans were in England" (Edgeworth, 1822, I: 128) becomes "era una delle poche reliquie che attestano il soggiorno fatto dai Romani nella Lombardia [it was one of the few remains of the stay of the Romans in Lombardy]" (Edgeworth, 1839: 115).

In English, Frank had his Roman kings, consuls, and emperors on one side of the room and Mary her English kings and queens on the floor on the other (Edgeworth, 1822, I: 137), whereas, in Italian, Benedetto has the Roman consuls and emperors and Maria has the Italian kings and dukes (Edgeworth, 1839: 124). Instead of having Frank's father explain about a legal case (Edgeworth, 1822, I: 227), the target reader is distracted with a long explanation about a tour (Edgeworth, 1839: 227-228). Milesi also concentrates on Roman history:

This led to an inquiry, which ended in putting a stop to all visiting between the kings and queens of England and the kings and consuls of Rome. The time of Julius Cesar's landing at Deal was inquired into, and, to please Mary, he and the emperor Augustus Caesar were permitted to see Queen Boadicea, though, as Frank observed, this was absolutely impossible in reality, because Queen Boadicea did not live till eighteen years afterwards They went to their little histories of England, France, and Scotland, and found all the kings and queens, and remarkable people, who live at the same time; and they amused themselves with making out parties for these personages, and inventing conversations for them (Edgeworth, 1822, I: 137).

Questa osservazione condusse a un discorso, il quale interruppe ogni visita fra le regine e le duchesse d'Italia, e fra i re e i consoli di Roma. S'investigò l'epoca in cui i consoli Gneo Cordelio Scipione e Marco Marcello conquistarono l'Insubria e portarono sino a Milano la dominazione di Roma l'anno 221 prima dell'era volgare. Menzionarono i bellissimi avanzi delle terme erculee in Milano, denominate ora le Colonne di S. Lorenzo. Passarono quindi ai compendii di storie del ducato di Milano, della repubblica di Venezia, della repubblica Fiorentina, di Pisa; di Genova; e trassero fuoiri i duchi, le duchesse, i dogi, i gonfalonieri e le persone più notabili che vivevano nello stesso tempo; e si compiacquero nel recitare la parte di que'personaggi, inventando i dialoghi loro [This observation led to a speech, which ended any visit between the queens and the duchess of Italy, and between the kings and the consuls of Rome. The time when the consuls Gneo Cordelio Scipione and Marco Marcello conquered Insubria and took to Milan the Roman domination in 221AD was inquired into. They mentioned the good progress of the Herculean thermal spas in Milan, now called Saint Lawrence Columns. Then they talked about various stories of the dukedom of Milan, the Republic of Venice, the Republic of Florence, of Pisa ; of Genoa; and concluded with the dukes, the duchesses, the doges, the gonfalonieri and the most notable people who lived at that time, and they were pleased to recite the part of each of the characters, inventing their dialogues] (Edgeworth, 1839: 125).

Another change is "and while he was asked some question about a tower on his own estate, which was said to have been built in the time of Augustus Cesar, he said, he thanked his stars he knew nothing at all of any of the Caesars since he had left school, 
except his dog Caesar, who was worth them all put together" (Edgeworth, 1822, I: 129) translated as

e quando gli si fecero alcune domande intorno ad alcuni ruderi appartamenti alle antiche stazioni militari romane poste alla guardia dell'Italia, e che si trovavano in un suo podere, vicino alla chiesa d'Agliate, edificata ne'bassi tempi, ove dai materiali impiegativi appartenenti ad antica costruzione si deduce che presisteva colà un tempio dedicato a Nettuno, egli rispose che per fortuna sua, dachè aveva lasciato in collegio, non aveva saputo più altro di Nettuno, se non che del suo cane Nettuno, il quale importava ben più a lui che non il messere dal tridente [and when they asked him about the ruined apartments and the old Roman military stations established to protect Italy, which were in his power, next to the church of Agliate built in the temples where they used materials belonging to the old building, it was clear that there was a temple dedicated to Neptunus. He answered that fortunately since he had dropped school, he had not known about Neptunus, but about his dog Neptunus and that he was worth them all put together] (Edgeworth, 1839: 116).

The explanation of the cake for Twelfth Night is different: in the English text it is said that people play roles which are distributed by taking a piece of paper from a hat (Edgeworth, 1822, II: 96). In Italian, the element of the bean inside the cake determining the King/Queen of the evening is introduced (Edgeworth, 1839: 359). Also, "his next Midsummer holidays" (Edgeworth, 1822, II: 103) turns into "le prossime vacanze di settembre [next September holidays]" (Edgeworth, 1839: 358).

Cultural references are adapted to the Italian context. Pope's translation of Homer's Iliad (Edgeworth, 1822, I: 224) becomes 'L'Illiade d'Omero tradotta dal Monti [Omer's Iliad translated by Monti]" (Edgeworth, 1839: 215) and Plutarch's Lives (Edgeworth, 1822, II: 106) is "Vite degli uomini illustri [Lives of famous men]" (Edgeworth, 1839: 361). Tyrannus in Greek (Edgeworth, 1822, II: 88) appears as "Virgilio ed Edipo in Greco [Virgil and Oedipus in Greek]" (Edgeworth, 1839: 342).

The result of such adaptation may cause ambiguity: "The catalogue of Bullock's Museum" (Edgeworth, 1822, I: 29) is rendered as "Catalogo d'un museo o d'un gabinetto di storia naturale [catalogue of a museum or a cabinet on natural history]" (Edgeworth, 1839: 15) and the translator locates the museum in Pavia. "Many a one has turned out a mere fox-hunter, because he was not allowed to ride when he was a boy" (Edgeworth, 1822, I: 67, my italics) becomes "Alcuni hanno preso una passione pazza per andar a cavallo, perchè essendo ragazzi, non fu loro concesso di cavalcare, o perchè derisi di tal divieto dai loro compagni [some had turned out to be fox-hunters because they were not allowed to ride when they were children or because they were made fun of their company]" (Edgeworth, 1839: 55, my italics).

Neither sweetbriar nor honey-suckle are translated (Edgeworth, 1839: 292), but, if a cultural reference has passed into universal culture, then it is preserved: "Homer's Iliad, Achilles, Hector and Archilochus" (Edgeworth, 1822, I: 95) and Giacomo Ferguson's story (Edgeworth, 1822, II: 249) are retained in Milesi's text, as well as Robinson Crusoe, to whom repeated allusions are made. Excerpts in French from a book are not 
translated into Italian (Edgeworth, 1839: 45), and "Cabinet des Fées" (Edgeworth, 1822, II: 98) is also preserved (Edgeworth, 1839: 352).

Shavit mentions tone, accepted social norms, and undesirable events as some norms to be taken into account when one writes for children (1981: 172). In this sense, there is one plot shift in Italian, since, in the original text, a letter arrives announcing that Frank is not admitted to the school (Edgeworth, 1822, II: 110) while, in Italian, there is a vacant place for Benedetto, and he must be at school on Monday (Edgeworth, 1839: 366). There is a long story inserted here and we find a literal translation much later (Edgeworth, 1822, II: 249; Edgeworth, 1839: 366).

For Lawrence Venuti, what is translated and the ways it is published, reviewed and taught are part of cultural political practice: "constructing or critiquing ideologystamped identities for foreign cultures, affirming or transgressing discursive values and institutional limits in the target-language culture" (1995: 19). The opposite of domesticating translation is foreignizing it which signifies the difference of the foreign text and it entails registering the linguistic and cultural differences of the foreign text (1995: 81). When Milesi wants to approximate to English idioms and collocations, the result is not always successful, and on other occasions, she simply prefers to suppress these. Thus, at a microtextual level, Milesi tries to find equivalent terms for idiomatic expressions: "You'll never do at school - you'll be sent to Coventry", (Edgeworth, 1822, I: 81) becomes " "Non farete nulla in collegio: ve ne faranno di tutt'i colori [you will never do at school, you will be ignored]"' (Edgeworth, 1839: 68) and "To have another fish to fry" (Edgeworth, 1822, I: 22) is rendered as "altre gatte da pelare [to have something better to do]" (Edgeworth, 1839: 8). However, wordplay disappears. Tom says " "you'll be hissed out of the world"" Mary looked frightened, but Frank answered, that he believed he could not be hissed out of the world, because it was round" (Edgeworth, 1822, I: 81) but Milesi does not keep this; however, "fagots and maggots" (Edgeworth, 1822, I: 124) turns into "fastello e fardello [bundles and burdens]" (Edgeworth, 1839: 111). The wordplay with "apes/apis" (Edgeworth, 1822, I: 244) is suppressed and the distinction "Hoarse/coarse" (Edgeworth, 1822, II: 62) similarly disappears (Edgeworth, 1839: 314). Mungo's song (Edgeworth, 1822, I: 164) is translated, but a footnote with Benedetto's new version of the song is added (Edgeworth, 1839: 152). Finally, to "make a Miss Molly of such a fine little fellow" (Edgeworth, 1822, I: 206) is rendered as "voglia effeminare un ragazzo [to make a boy effeminate]" (Edgeworth, 1839: 196).

\subsection{Addition of new information}

Shavit stresses that the translator is sometimes even forced to add to the model elements which do not exist in the original text, but which are considered obligatory in the target model and are thus needed to strengthen it (1981: 172-173). In Milesi's case, this translation procedure makes the text easier for the Italian reader. Thus, Mrs. J. says that Tom is "quite a little bear" (Edgeworth, 1822, I: 75) and in Italian he is called "un vero orso e un maiale [truly a bear and a pig]" (Edgeworth, 1839: 62) and "you are positively 
quite a little epicure - absolutely a little cormorant" (Edgeworth, 1822, I: 75) becomes "sei proprio un leccone [you are really greedy]" (Edgeworth, 1839: 62). There are some expansions, such as "they earned bread for themselves and their families, by teaching French grammatically" (Edgeworth, 1822, I: 113), which turns into "insegnado la lingua francese in Inghilterra, in Germania, in Italia, e dappertutto ove si trovavano [by teaching French in England, in Germany, in Italy and wherever they were]" (Edgeworth, 1839: 100). "I had great respect for a poor French nobleman's son, who turned drawing master, and was obliged to work hard" (Edgeworth, 1822, I: 113) becomes "pel povero figlio di un emigrato fancese che conobbi in Inghilterra anni sono [for the poor son of the French émigré I met in England some years ago]" (Edgeworth, 1839: 100). "He told another anecdote of a French emigrant; no less a person than the present Duke of Orleans" (Edgeworth, 1822, I: 115) is rendered as "il quale era niente meno che il duca d'Orleans, il presente re dei Francesi [who was no less than the Duke of Orleans, currently the King of France]" (Edgeworth, 1839: 102). "It is from a play of Shakespeare" (Edgeworth, 1822, I: 120) turns into "Gli è un verso d'una tragedia di Shakespeare [it is taken from a tragedy by Shakespeare]" (Edgeworth, 1822, I: 107) and the translation into Italian is added: "Un'ambulante foresta viene a Dunsinane [a crowd of peddlars comes to Dunsinane]". Sometimes more information than in the original appears: "From the little books of history, which he had read, he knew that 'the Romans in England once did sway;' but he had thought of this only as a circumstance mentioned in books" (Edgeworth, 1822, I: 128) is "Da quel poco di storia che aveva letto, sapeva Benedetto che i Romani avevano dominata la Gallia cisalpina, nome antico della Lombardia [from the little history he had read, Benedetto knew that the Romans had dominated Cisalpine Gaul, the old name of Lombardy]" (Edgeworth, 1839: 115).

In the change from English to Italian, information can become more specific: "now in the palace of the Duke of Orleans in France" (Edgeworth, 1822, I: 116) turns into "nel palazzo del duca d'Orléans a Parigi [in the palace of the Duke of Orleans in Paris]" (Edgeworth, 1839: 103) and "a pair of scarlet worsted cuffs, or bracelets, by some called wristlets, by others comfortables, by others muffatees by others kitty cuffs" (Edgeworth, 1822, I: 186) becomes "un paio di mezzi guanti a maglia di lana rossa [a pair of pink woolen half gloves]" (Edgeworth, 1839: 174).

According to Peter Hunt, there is a parallel between the emergence of children's literature and other new literatures (national, ethnic, post-colonial). Children's literature had to fight against the academic hegemony of English literature to gain recognition (1992: 2) and the paternalistic attitude to children's literature has a parallel in new literatures. Apart from her commitment to her country, expressed through her choice of the Tuscan dialect, Milesi in some instances reveals other sympathies: "The conversation next turned upon one of those old towers which are called Cesar's towers, and various facts of history were mentioned" (Edgeworth, 1822, I: 128) is rendered into Italian with patriotic overtones:

e quando gli si fecero alcune domande intorno ad alcuni ruderi appartamenti alle antiche stazioni militari romane poste alla guardia dell'Italia, e che si trovavano in un suo podere, vicino alla chiesa d'Agliate, edificata ne'bassi tempi, ove dai materiali impiegativi 
appartenenti ad antica costruzione si deduce che presisteva colà un tempio dedicato a Nettuno, egli rispose che per fortuna sua, dachè aveva lasciato in collegio, non aveva saputo più altro di Nettuno, se non che del suo cane Nettuno, il quale importava ben più a lui che non il messere dal tridente [and when they asked him about the ruined apartments and the old Roman military stations established to protect Italy, which were in his power, next to the church of Agliate built in the temples where they used materials belonging to the old building, it was clear that there was a temple dedicated to Neptunus. He answered that fortunately since he had dropped school, he had not known about Neptunus, but about his dog Neptunus and that he was worth them all put together] (Edgeworth, 1839: 116).

Il discorso versò alla scarsezza dei monumenti romani che si rivengono in Lombardia, quantunque Milano sia pure stata lungo tempo sede degli imperatori. Ne accagionavano della distruzione quasi totale l'essere state queste pianure il primo campo sul quale s'era sfogata la cieca rabbia delle orde barbariche, le quali inondarono successivamente la povera Italia! [the conversation turned to the scarcity of Roman monuments in Lombardy although Milan has long been the seat of Emperors. Blame for the almost total destruction was placed on the fact that this plain was the first place where the blind fury of the barbaric hordes who progressively flod Italy was vented] (Edgeworth, 1839: 145-146, my italics).

There is a long explanation about the origin of fruits taken from Gallesio (Edgeworth, 1839: 232-233). Sometimes, if a reference to English culture is preserved, another in Italian is added. For instance, Gay is related to Gallesio's Pomona Italiana (Edgeworth, 1839: 201) and also to the references to Alexander, General Wolfe and Nelson, the "Price of Victory" in "Evenings at Home" (Edgeworth, 1839: 205), and Franklin (Edgeworth, 1839: 209). When they talk about peaches, the translator not only identifies the variety "biancona di Verona" (Edgeworth, 1839: 231), but she also explains in a note what it is; another footnote is included on added about the types of bats in Colombia (Edgeworth, 1839: 14).

\section{Conclusion}

Maria Edgeworth's enlightened Utilitarian views were very successful in Great Britain due to her didactic vein and writing style, full as it is with scholarly references. Though this feature might have shocked some continental readers, Frank could have been translated more literally into Italian by keeping the setting and allusions in Edgeworth's story, as occurred in France and Spain (Fernández, 2008; 2010). Furthermore, Edgeworth uses neither an innovating pattern nor deviates from conventional literary forms. The content of the story is suitable for young readers and fits perfectly into the authoress's corpus. However, the Italian text concurs with the belles infidèles method which privileged adaptation to the target language and culture which prevailed in Europe during the eighteenth century and a good deal of the nineteenth century (Mounin, 1994).

The text produced by Milesi changes the setting from England to Lombardia and there is a quantitative reduction of paratexts and cultural allusions leading to the loss of the original function of certain elements, whose absence reveals much about the 
translator's aim. Cultural references tend to be replaced by others referring to Italy, which affects the main plot despite the fact that characters are retained and Milesi makes an effort to accommodate speech and produce a less pedantic and verbose text.

As this analysis has shown, Benedetto is poised between foreignization and domestication in that Milesi retains some elements from Edgeworth's story but reduces the text to Italian cultural values. From a twenty-first century perspective, the changes in Benedetto point to an adaptation into Italian rather than a translation, and the fact of being "children's literature" is no excuse. Nevertheless, manipulating the source text was common practice and Milesi clearly wants to give a political dimension to Edgeworth's story. With this work, Milesi reveals her allegiances and participates in the formation of national culture, and at the same time facilitates the incorporation of the work of a well-known British writer in the Italian canon for children's stories.

\section{Notes}

1. This essay is part of the outcome of the research group Rede de Lingua e Literatura Inglesa e Identidade II, R2014/043, Xunta de Galicia. I would like to thank Licia Berdini Massi (EOI A Coruña) and Marco Delle Monache (EOI Ferrol), who kindly helped me to revise the translation from Italian.

2. However, modern translations of Edgeworth into Italian include Pietro Meneghelli's Il Castello Rackrent (Roma: Fazi Editore, 1992) and Chiara Vatteroni's Se nasce femmina (Milano: Tranchida Editori Inchiostro, 1996).

3. Milesi also wrote Cenni per miglioramento della prima educazione da fanciulli (Milano: presso A.F. Stella e Figli, 1830).

4. Milesi had two children, Benito and Enrico.

5. Miliken (Edgeworth, 1822, II: 73) is later translated as "Billy" (1839: 325).

\section{References}

Antologia: giornale di scienze, lettere e arti (1831): Vol XLI della collezione. Volume primo del secondo decenio. Gennaio, febbraio e marzo. Firenze: al Gabinetto Scientifico e letterario di G. P. Vieusseux. Dir. E Edit. Tipografia di Luigi Pezzati.

Biblioteca italiana o sia giornale di letterature, scienze ed arti compilato da vari letterati (1829): Tomo LV. Luglio, agosto e settembre Milano: presso la direzione del giornale.

Bravo Villasante, Carmen (1989): Ensayos de literatura infantil. Murcia: Secretariado de la Universidad.

Butler, Marilyn (1972): Maria Edgeworth: A Literary Biography. Oxford: Clarendon Press.

Colvin, Christina (1979): Maria Edgeworth in France and Switzerland: Selections form the Edgeworth Family Letters. Oxford: Clarendon Press.

Edgeworth, Maria (1822): Frank, A Sequel to Frank in Early Lessons. Two volumes. Cambridge: Hilliard and Metcalf.

(1839): Benedetto. Traduzione di Bianca Milesi Mojon. Milano: Vedova di A.F. Stella e Giacomo Figlio. 
Even-Zohar, Itamar (1990): “The Literary Polysystem”. Poetics Today 11: 9-44.

(1990): "The Position of Translated Literature within the Literary Polysystem". Poetics Today 11: 45-51.

Fernández Rodríguez, Carmen María (2008): "Un Oriente muy poco convencional: 'Murad the Unlucky' de Maria Edgeworth y su traducción al francés y al castellano en el siglo XIX". Sendebar 19: 77-98.

- (2010): "Traducción y didactismo en el siglo diecinueve: "Mañana" y "Un acreedor" de Maria Edgeworth". Babel/AFIAL 19: 21-38.

- (2012): "Una traducción al castellano de 'The Manufacturers' (1809) de Maria Edgeworth". Hermeneus 14: 103-131.

(2013a): "Maria Edgeworth and Children's Literature: the Translation of The Parent's Assistant (1796) into Spanish". ES: Revista de Filología Inglesa 34: 131-150.

(2013b): “Whatever Her Faith May Be': Some Notes on Catholicism in Maria Edgeworth's oeuvre". Miscellanea: A Journal of English and American Studies 48: 29-44.

Genette, Gérard (1987): Seuils. Paris: Éditions du Seuil.

Guida dell'educatore (1836): Foglio mensuale. Redatto da Raff. Lambruschini. Anno primo. Firenze: al Gabinetto Scientifico e letterario di G. P. Vieusseux.

Hunt, Peter (1992): Literature for Children: Contemporary Criticism. London and New York: Routledge.

Klinberg, Göte (1986): Children's Fiction in the Hands of the Translators. Studia psychological et paedagogica. Series altera LXXXII. Lund: Bloms Boktryckeri Ab.

"Letteratura italiana" (1835): Indicatore ossia raccolta perodica di scelti articoli così tradotti come originali intorno alle letterature straniere, alle storie, alle scienze fisiche ed economiche, etc. Tomo due. Milano: Topografia e libreria Pirotta, 440-446.

Maroncelli of Forli, Piero (1836): Additions to 'My Prison's, Memoirs of Silvio Pellico. Cambridge: Charles Folsom.

McWhorter Harden, O. Elizabeth (1971): Maria Edgeworth's Art of Prose Fiction. The Hague and Paris: Mouton.

Mounin, Georges (1994): Les belles infidèles. Paris: Presses Universitaires de Lille.

Newmark, Peter (1995): A Textbook of Translation. New York \& London: Prentice Hall Macmillan.

Peña Muñoz, Manuel (1994): Alas para la infancia: fundamentos de literatura infantil. Santiago de Chile: Editorial Universitaria.

"Rivista di opere sull'educazione popolare" (1846): Rivista Europea: giornale di scienze morali, letteratura ed arti. Milano: Tipografia da Giuseppe Redaelli: 228-44.

Scott, Walter (1877) [1814]: Waverley. Edinburgh: Adam and Charles Black. Vol II.

Shavit, Zohar (1981): "Translation of Children's Literature as a Function of Its Position in the Literary Polysystem". Poetics Today, 2. 4: 171-179.

Snell-Hornby, Mary (1995): "On Models and Structures and Target Text Cultures: Methods of Assessing Literary Translations". In J.M. Borillo, ed., La traducció litèraria. Castelló de la Plana: Publicacions de la Universitat Jaume I, 43-58.

Souvestre, Émilie (1854): Bianca Milesi-Mojon: notice biographique. Angers: Imprimerie de Cosnier et Lachèse.

Toury, Gideon (1995): Descriptive Translation Studies and Beyond. Amsterdam/ Philadelphia: John Benjamins Publishing Company.

Venuti, Lawrence (1995): The Translator's Invisibility: A History of Translation. London and New York: Routledge. 